\title{
Correlation of sperm DNA damage with blastocyst formation: systematic review and meta-analysis
}

\author{
Prashanth K. Adiga' ${ }^{1}$, Srisailesh Vitthala ${ }^{2,3^{*}}$ (1) and Shivaranjeni ${ }^{4}$
}

\begin{abstract}
Background: The routine semen analysis fails to detect sperm DNA damage which contributes to the majority of male factor infertility. Sperm DNA fragmentation test (DFI) measures the sperm DNA damage. Blastocyst formation is an important step in IVF \pm ICSI. At present, the literature lacks any data that correlates DFI and blastocyst formation.

Main body of the abstract: We searched MEDLINE and other databases till 2020 for the studies that reported on sperm DNA damage and blastocyst formation in assisted reproductive technology (ART). The outcomes analyzed were (1) a comparison of blastulation rates in high DFI and low DFI groups. (2) Comparison of blastulation rates in high DFI and low DFI groups based on (a) different sperm DNA fragmentation assays (COMET, SCD, SCSA, TUNEL), (b) different types of ART (IVF/IVF + ICSI/ICSI). 10 studies were included in this review. A non-significant increase in the blastocyst formation was observed in high $\mathrm{DFI}$ group $(\mathrm{OR}=0.70 ; 95 \% \mathrm{Cl}=0.4$ to $1.21 ; P=0.20)$ and with $\mathrm{SCD}$ and TUNEL assays.

Short conclusion: Our study emphasizes on sperm DNA fragmentation (sperm DNA damage) as an important marker of blastocyst formation. The results of this meta-analysis suggest that the high sperm DNA fragmentation may not adversely affect the blastocyst formation.
\end{abstract}

Keywords: DFI, Blastocyst, IVF, ICSI, ART

\section{Background}

Sperm is the motile male gamete with the ability to capacitate, penetrate, and fertilize the oocyte (female gamete) to form a blastocyst (implantable embryo). Sperms are remarkably complex cells with a single important mission to deliver paternal DNA (male genetic material) and its associated factors to the oocyte to start a new life [20,24]. This function is carried out successfully due to modified DNA architecture in the spermatic nucleus wherein protamines replace histones and adopt doughnut shape configuration. This modification is called chromatin condensation of spermatic DNA and any disruption or disturbance in the condensation

\footnotetext{
*Correspondence: srivitt@yahoo.com

${ }^{3}$ Honorary Associate University of Aberdeen, Aberdeen, UK

Full list of author information is available at the end of the article
}

process will lead to unsuccessful conception/pregnancy in humans [12]. The male factor infertility is an important cause of infertility. Sperm DNA damage contributes to the majority of male factor infertility because of damage or defects in chromatin condensation of spermatic DNA [15, 31, 51].

Semen analysis remains the cornerstone of the evaluation of the infertile man and is widely used to evaluate and predict the fertilization capability of sperm [24]. Semen parameters routinely evaluated are sperm concentration, motility, live sperm ratio, and morphological examination [51]. However, routine semen analysis fails to identify sperm DNA damage $[14,40]$.

Many patients with male factor infertility need Assisted Reproductive Technology (ART) such as intracytoplasmic sperm injection (ICSI) for successful conception with limited success $[1,42]$. Sperm (male gamete) with high 
DFI may result in poor fertilization and poor blastocyst formation, ultimately leading to poor pregnancy rates $[29,49]$. However, the effect of sperm DNA damage (high DFI) on fertility outcomes are contentious. The metaanalysis by Simon et al. suggests that sperm DNA damage affects clinical pregnancy following IVF and/or ICSI treatment [46], whereas studies by Zhang et al., Chi et al., Yang et al., and Chen et al. have not shown that high DFI affects the outcome of ICSI $[8,9,52,54]$.

The test developed to assess the measure of sperm DNA damage is called sperm DNA fragmentation test, and its value is expressed as sperm DNA fragmentation index (DFI) $[7,20]$.

DFI is expressed as the percentage of DNA-damaged sperms in the total ejaculate. The value of DFI is related to the extent and type of sperm DNA damage and may also predict the reproductive outcomes [25].

Currently, there are 4 widely used techniques to calculate the level of sperm DNA damage such as comet assay, sperm chromatin structure assay (SCSA), sperm chromatin dispersion test (SCD), and Tunel assay (terminal deoxynucleotidyl transferase dUTP nick end labeling). Each assay measures different aspects of sperm DNA damage [21, 32, 33].

i. Comet assay is used to study single- or doublestrand DNA breaks and measures the migration of the DNA fragments in the electric field. The intensity of the comet tail represents the amount of fragmented DNA.

ii. In the SCSA, the extent of DNA damage is measured by the metachromatic shift from green fluorescence to red fluorescence following acid denaturation and acridine orange staining.

iii. In the SCD assay, sperm with fragmented DNA fails to produce the characteristic halo following acid denaturation and removal of nuclear proteins.

iv. The TUNEL assay quantifies the level of labeled nucleotide incorporated at single- and doublestrand DNA breaks in a reaction catalyzed by the template-independent enzyme deoxynucleotidyl transferase.

When DFI is $\leq 20 \%$, the fertility potential is assumed to be good for SCSA [48], while it is considered good if DFI is $\leq 30 \%$ for SCD [5, 34] and TUNEL test [4].

Despite differences in the principle and methodology of DFI assays, the levels of DNA damage measured by these assays show a degree of correlation [21, 32, 33].

Sperm DFI has been hypothesized as one of the investigations to differentiate between infertile and fertile men [58] but not recommended in the initial evaluation of the infertile couple by ASRM guidelines on the basis of grade C evidence [41].

Male infertility with relatively high fragmented DNA (represented as high sperm DNA fragmentation indexDFI) may correlate with a low number and quality blastocysts which will negatively affect the pregnancy even after ICSI. Thus, blastocyst formation assumes paramount importance in patients with sperm DNA damage $[33,43,50]$.

The published data regarding the actual blastocyst formation in relation to sperm DNA damage are limited because they have focused only on the outcomes of pregnancy rates. The objective of this study was to evaluate the actual blastocyst formation in patients with increased damaged sperm DNA.

\section{Main text}

The review is reported according to Preferred Reporting Items for Systematic Reviews and Meta-Analyses (PRISMA).

\section{Literature search}

We searched MEDLINE, EMBASE, CINAHL, Google Scholar, Web of Science databases, and SCISEARCH from the inception of the database to January 2020 for studies that reported on sperm DNA damage and blastocyst formation in assisted reproductive technology (ART). We also manually reviewed the bibliographies of retrieved original papers, review papers, previous metaanalyses, and relevant studies for additional articles. In this way, missing data from our search criteria were identified and included.

A computerized search was performed using the Medical Subjects Headings (MeSH) search strategy to generate two subsets of citations. One subset included the search terms and words related to "sperm DNA damage," "sperm DNA fragmentation," "sperm DNA integrity," or "sperm DNA" along with "Comet," "TUNEL," "SCSA," "Acridine orange," "Halo," or "SCD."

The other subset included the search terms and words related to "ART," "IVF," "ICSI," "Late embryo development," "blastocyst," "embryo," or "day 5 culture."

Both subsets were combined and searched again to capture all the relevant articles or citations for our study. The search was restricted to clinical studies in human subjects.

Two authors (SV and PK) conducted the search and reviewed them independently. The discrepancies for inclusion and exclusion of the studies were resolved by group consensus with other reviewers.

Authors were contacted whenever possible if full manuscripts or translations were not available. We also considered the inclusion of studies that collected relevant 
data but were excluded from the previous meta-analysis due to the inability to extract two-by-two tables.

\section{Inclusion criteria and study selection based on outcomes}

Sperm DNA damage involves DNA fragmentation, breakage of DNA cross-links (single or double strands), abnormal protamination, and chromatin condensation. For the purpose of our review and meta-analysis, we included studies that looked into sperm DNA fragmentation or breakage of DNA cross-links (single or double strands) and reported DNA damage as either low DFI (sperm DNA fragmentation index) or high DFI in the couples who underwent Invitro fertilization (IVF)/intracytoplasmic sperm injection (ICSI) as treatment of their infertility. In the studies included, the female demographics responsible for infertility were comparable and hence the inconsistencies with regard to female factors were also comparable. The male factors like varicocele, infections, and smoking also contribute to sperm DNA damage (Smith [47]). In this study, we tried to find out the impact of DFI on blastocyst formation.

\section{Outcomes}

- Our main outcome of interest was to compare blastulation rates in two groups viz., high DFI (high sperm DNA fragmentation) and low DFI (low sperm DNA fragmentation), based on the percentage of sperm DNA damage expressed as DFI.

(Blastulation rate is defined as the rate of blastocyst formation resulting from in vitro fertilization (IVF)/ intracytoplasmic sperm injection (ICSI) of metaphase II (M II) oocytes with sperm DNA damage expressed as high or low DFI).

Our other outcomes of interest were to compare of blastulation rate in high DFI and low DFI sperm DNA fragmentation groups based on the following:

i. Different sperm DNA fragmentation assays (COMET, SCD, SCSA, TUNEL).

ii. Different types of ART treatments (IVF/ IVF + ICSI/ICSI).

\section{Inclusion criteria}

Studies were included if they analyzed the relationship between the following:

i. Sperm DNA fragmentation detected by the Comet, SCSA, SCD, or TUNEL assays ii. Blastocyst formation in couples who underwent ICSI, IVF, or mixed (IVF + ICSI)

iii. Blastulation rate (blastocyst formation rate): sufficient data available to calculate the blastocyst formation rate from the studies (number of blastocysts after fertilization of M II oocytes either by ICSI, IVF, or mixed (IVF + ICSI) and sperm damage was reported by DFI).

\section{Exclusion criteria}

The following studies were excluded from our analysis that did report on the following:

i. Studies measuring sperm DNA fragmentation using slide-based acridine orange staining method or any other methods other than COMET, SCSA, SCD, and TUNEL assays.

ii. Studies that did not define sperm DNA fragmentation as low and high DFI.

iii. Studies which did not report on blastocyst formation.

iv. Studies with insufficient data on blastocysts formation to construct $2 \times 2$ table.

v. Studies were excluded if they had no original data available for retrieval or overlapping or duplication of the data.

\section{Data collection and extraction}

Data extraction was done by selecting the titles and abstracts, from the electronic search using the search strategy mentioned. They were scrutinized independently by reviewers (SV, SR, and PK). Full manuscripts of studies that fulfilled our selection criteria were retrieved. The inclusion and exclusion of studies were decided after careful evaluation of the full manuscripts.

The information extracted from the included articles to perform the meta-analysis is as follows: name of the author, year of publication, study design, type of ART treatment (ICSI, IVF, IVF + ICSI), and method of sperm DNA fragmentation assay, after excluding the female factors. The two-by-two table was constructed for the blastulation rate (number blastocysts formed in low and high DFI groups).

\section{Statistical analysis}

We retrieved the data for each individual study with respect to the number of blastocysts formed from the total number of metaphase 2 (M II) oocytes from IVF/ ICSI cycle.

The outcomes were summarized as the comparison of pooled odds ratio (OR) with 95\% CI for blastocyst 
formation in the high DFI (high sperm DNA fragmentation) group and low DFI (low sperm DNA fragmentation) group.

We also performed separate subgroup meta-analyses in different sperm DNA fragmentation methods and also in different types of ART treatments (ICSI/IVF, IVF + ICSI) for the same pooled odds ratio (OR) with $95 \%$ CI for blastocyst formation in high and low groups of DFI.

We used the random effect models for meta-analysis to calculate an overall OR and its 95\% confidence intervals (CI) with the forest plots.

We used the Review Manager [RevMan] Version 5.3. Copenhagen: The Nordic Cochrane Centre, The Cochrane Collaboration, [38] to perform these metaanalyses. The presence of heterogeneity was assessed by the $I^{2}$ statistic. An $I^{2}>50 \%$ was taken to indicate substantial heterogeneity. Heterogeneity of the exposure effects was evaluated graphically using forest plots and statistically using the $I^{2}$ statistic to quantify heterogeneity across studies.

The random effects model was used to calculate the odds risks if the $I^{2}$ statistic was greater than 50\%. Exploration of the causes of heterogeneity was planned using variation in features of the population, exposure, and study quality.

\section{Sensitivity analysis}

A sensitivity analysis was conducted by repeating metaanalyses in following ways: Excluding and including retrospective studies, applying fixed as well as random effect models to note any effect on the outcomes. We also performed subgroup analysis of the studies comparing different DFI cutoff values to note any effect on the outcomes.

\section{Results of the search}

A total of 1272 citations were initially identified after electronic search and 1249 citations were excluded after screening the titles and /or abstracts. A total of 23 publications were identified and scrutinized in full text in Fig. 1-PRISMA.

Thirteen studies were excluded with reasons, and a total of 10 studies were included for the meta-analysis.

Study characteristics are summarized in Tables 1 and 2. Included studies are presented in Table 1.

A total of ten studies were included in the meta-analysis. Of those, five were prospective $[4,5,34,44,48]$ and the remaining five were retrospective studies $[16,17,43$, 56]. There were no randomized controlled studies based on these outcomes.

Excluded studies are presented in Table 2.
Thirteen studies were excluded from the meta-analysis. Of those, eight studies [2, 3, 22, 25, 37, 45, 50, 53] had insufficient data on blastulation rates.

Two studies (Muriel et al. [30]; Loutradi et al. [28]) did not define the low and high DFI threshold for sperm DNA fragmentation, one study [19] had inappropriate inclusion of only high DFI, one study [11] reported on sperm DNA methylation defects rather than sperm DNA fragmentation, and one study (Piccolomini et al. [36]) reported on analyzed.

Outcomes: Comparison of blastulation rates in low DFI and high DFI groups are presented in Figs. 2a, b.

A total of 9083 blastocysts were formed from 22,369 metaphase II oocytes from the 10 studies included. Overall, non-significant increase in the blastulation rates was observed in the high DFI group in comparison to the low DFI group. The combined pooled odds ratio (OR) with confidence intervals $(\mathrm{CI})$ are as follows: random $\mathrm{OR}=0.75 ; 95 \% \mathrm{CI}=0.4$ to $1.21 ; P=0.20 ; I^{2}$ (inconsistency) $=98 \%$. Fixed $\mathrm{OR}=0.85 ; 95 \% \mathrm{CI}=0.79$ to 0.92 ; $P \leq 0.00001$.

A sensitivity analysis was conducted by repeating metaanalyses by excluding and including retrospective studies did not show any difference in the outcomes. Similarly, subgroup analysis comparing different DFI cutoff values also did not show any difference in the outcomes as shown in Fig. 2a, b.

Our other outcomes of interest were to compare of blastulation rate in high DFI and low DFI sperm DNA fragmentation groups based on the following:

- Different sperm DNA fragmentation assays (COMET, SCD, SCSA, TUNEL).

- Different types of ART treatments (IVF/IVF+ICSI/ ICSI).

Various methods of sperm DNA fragmentation assays with different cutoff values of high and low DFI are the confounding factors that can affect the blastulation rates. Therefore, subgroup analysis was performed to compare blastulation rates in different sperm DNA fragmentation assays as shown in Fig. 3a, b.

The blastulation rates in the four SCD studies were pooled. Non-significant increase in blastulation rates were observed in high DFI group in comparison to low DFI group. The combined pooled OR with CI are as follows: random pooled $\mathrm{OR}=0.52 ; 95 \% \mathrm{CI}=0.35$ to 0.78 ; $P=0.001 ; I^{2}$ (inconsistency) $=90 \%$ and fixed pooled fixed $\mathrm{OR}=0.6 ; 95 \% \mathrm{CI}=0.54$ to $0.67 ; P<0.00001$.

The blastulation rates in the three TUNEL studies were pooled, and increased blastulation rates were observed in high DFI group in comparison to low DFI group. The combined pooled OR with CI are as follows: pooled 


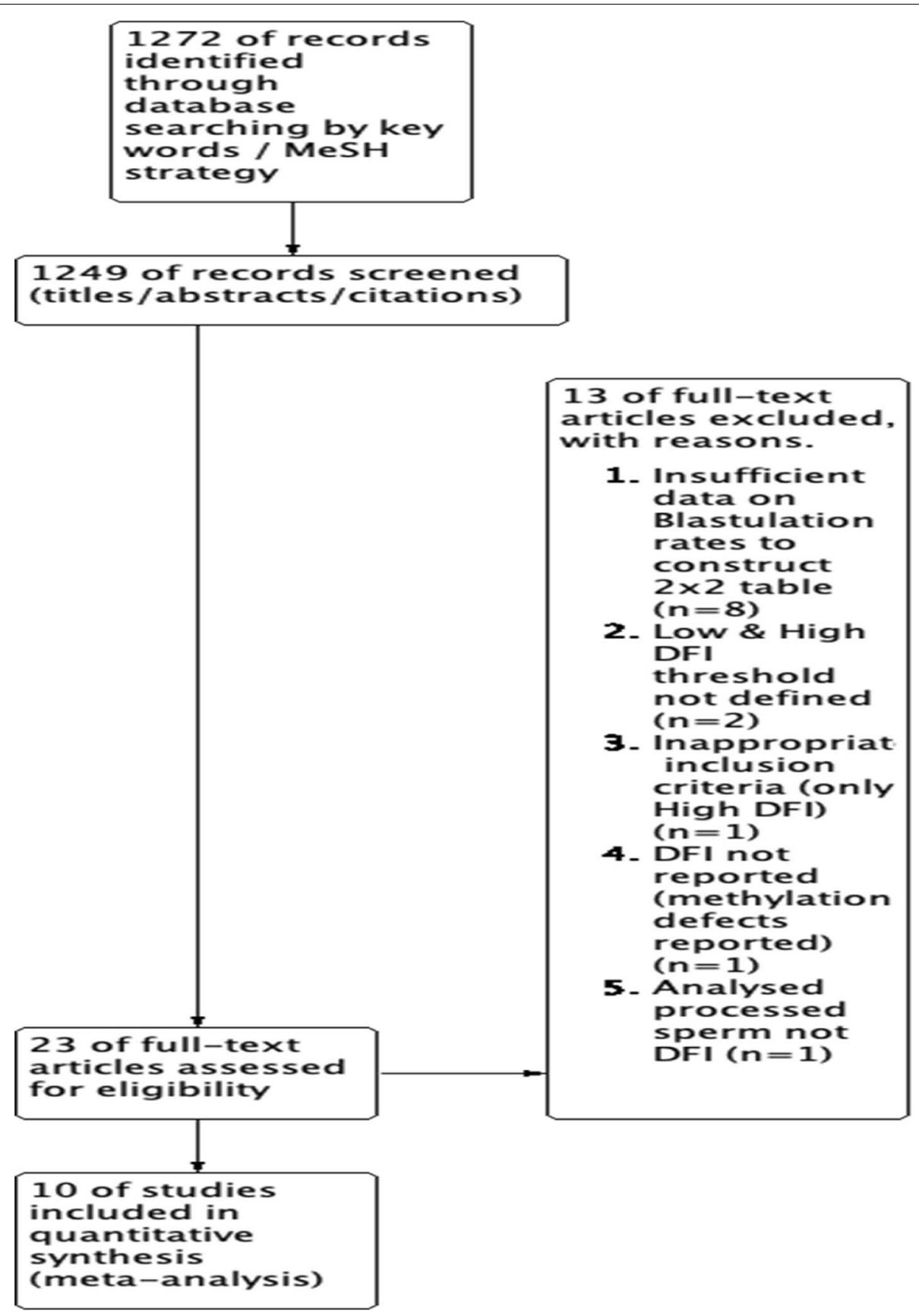

Fig. 1 PRISMA

random $\mathrm{OR}=0.44 ; 95 \% \mathrm{CI}=0.10$ to $1.91 ; P=0.27 ; I^{2}$ (inconsistency) $=98 \%$. Pooled fixed OR $=0.73 ; 95 \%$ $\mathrm{CI}=0.61$ to $0.87 ; P=0.0005$.

The blastulation rates in the three SCSA studies were pooled, and higher blastulation rates were observed in low DFI group in comparison to high DFI group. The combined pooled OR with $\mathrm{CI}$ are as follows: pooled random $\mathrm{OR}=1.56 ; 95 \% \mathrm{CI}=0.43$ to $5.6 ; P=0.5 ; I^{2}$ (inconsistency) $=99 \%$ and fixed pooled fixed $\mathrm{OR}=1.67$; $95 \% \mathrm{CI}=1.45$ to $1.93 ; P<0.00001$.

Different types of ART treatments (IVF/IVF + ICSI/ICSI)

Various methods of ART treatments (IVF/IVF+ICSI/ ICSI) can have different blastulation rates and that can 
Table 1 Study characteristics (included studies)

\begin{tabular}{|c|c|c|c|c|c|c|}
\hline S. No & Author year & Type of study & ART treatment & No. of cycles & $\begin{array}{l}\text { DNA } \\
\text { fragmentation } \\
\text { assay }\end{array}$ & $\begin{array}{l}\text { Low and high DFI } \\
\text { threshold cutoff }\end{array}$ \\
\hline 1 & Borges et al., [5] & Prospective & ICSI & $\begin{array}{l}475 \text { cycles } \\
\text { Low DFI } \\
n=42 \\
\text { High DFI } \\
n=433\end{array}$ & SCD & $\mathrm{DFI}<30 \% \& \mathrm{DFI}>30 \%$ \\
\hline 2 & Ni et al. [34] & Prospective & IVF/ICSI-FET & $\begin{array}{l}1082 \text { cycles } \\
\text { Low DFI } \\
n=910 \\
\text { High DFI: } \\
n=172\end{array}$ & SCD & $\mathrm{DFI}<30 \% \& \mathrm{DFI}>30 \%$ \\
\hline 3 & Zheng et al., [56] & Retrospective & IVF/ICSI & $\begin{array}{l}161 \text { cycles } \\
\text { Low DFI } \\
n=68 \\
\text { High DFI } \\
n=93\end{array}$ & SCD & $\mathrm{DFI}<10 \% \& \mathrm{DFI}>10 \%$ \\
\hline 4 & Garcia-Ferreyra et al., [16] & Retrospective & IVF/ICSIOD & $\begin{array}{l}32 \text { cycles } \\
\text { Low DFI }=05 \\
\text { High DFI = } \\
27\end{array}$ & SCD & $\mathrm{DFI}<17 \% \& \mathrm{DFI}>17 \%$ \\
\hline 5 & Speyer et al., [48] & Prospective & IVF/ICSI & $\begin{array}{l}347 \text { cycles } \\
\text { Low DFI } \\
n=297 \\
\text { High DFI } \\
n=50\end{array}$ & SCSA & $\mathrm{DFI}<20 \% \& \mathrm{DFI}>20 \%$ \\
\hline 6 & Gat et al., [17] & Retrospective & ICSI-FET & $\begin{array}{l}177 \text { cycles } \\
\text { Low DFI } n \\
=141 \text { High } \\
\text { DFI } n=36\end{array}$ & SCSA & $\begin{array}{l}\text { DFI }>30 \% \text { - high } \\
\mathrm{DFI}<15 \% \text { - low }\end{array}$ \\
\hline 7 & Gat et al. [17] & Retrospective & ICSI-OD-FET & $\begin{array}{l}45 \text { cycles } \\
\text { Low DFI } \\
n=18 \\
\text { High DFI } \\
n=27\end{array}$ & SCSA & $\mathrm{DFI}<15 \% \& \mathrm{DFI}>15 \%$ \\
\hline 8 & Benchaib et al., [4] & Prospective & IVF/ICSI-OD & $\begin{array}{l}322 \text { cycles } \\
\text { of ICSI + IVF } \\
\text { Low DFI } \\
n=87 \\
\text { High } \\
\text { DFI }=235\end{array}$ & TUNEL & $\mathrm{DFI}<30 \% \& \mathrm{DFI}>30 \%$ \\
\hline 9 & Seli et al., [44] & Prospective & IVF/ICSI & $\begin{array}{l}49 \text { cycles } \\
\text { Low DFI } \\
n=28 \\
\text { High DFI }=21\end{array}$ & TUNEL & $\mathrm{DFI}<20 \% \& \mathrm{DFI}>20 \%$ \\
\hline 10 & Sedo et al., [43] & Retrospective & IVF/ICSI/OD & $\begin{array}{l}82 \text { cycles } \\
\text { Low DFI } \\
n=54 \\
\text { High DFI }=28\end{array}$ & TUNEL & $\mathrm{DFI}<15 \% \& \mathrm{DFI}>15 \%$ \\
\hline
\end{tabular}

affect the outcomes. Therefore, a subgroup analysis was conducted in different ART treatment methods to compare the blastulation rates as shown in Fig. 4a, b.

The blastulation rates in the seven studies were pooled, and a non-significant increase in blastulation rates was observed in the high DFI group in comparison to the low DFI group.
The combined pooled odds ratio with confidence intervals are as follows: pooled random $\mathrm{OR}=0.68$; $95 \%$ $\mathrm{CI}=0.30$ to $1.54 ; \quad P=0.35 ; \quad I^{2} \quad$ (inconsistency) $=98 \%$ and pooled fixed $\mathrm{OR}=0.95 ; 95 \% \mathrm{CI}=0.85$ to 1.05 ; $P<0.00001$.

The blastulation rates in the four studies were pooled, and no significant difference in blastulation rates was observed in low and high groups of the DFI group. 
Table 2 Study characteristics (excluded studies)

\begin{tabular}{|c|c|c|c|c|c|}
\hline Serial no & Author and year & $\begin{array}{l}\text { Type of } \\
\text { assisted } \\
\text { treatment }\end{array}$ & Type of study, no. of cycles & $\begin{array}{l}\text { Sperm DNA fragmentation } \\
\text { assay }\end{array}$ & Reason for exclusion \\
\hline 1 & Benchaib et al. [3] & IVF/ICSI & $\begin{array}{l}\text { Prospective study } \\
n=104 \text { cycles } \\
\text { They have studied the } \\
\text { formation of day } 3 \text { and not } \\
\text { blastocysts }\end{array}$ & TUNEL & \multirow[t]{8}{*}{$\begin{array}{l}\text { Insufficient data on blastulation } \\
\text { rates and blastocyst formation } \\
\text { rates cannot be calculated }\end{array}$} \\
\hline 2 & Larson-Cook et al. [25] & IVF/ICSI & $\begin{array}{l}\text { Retrospective } \\
n=89 \text { cycles } \\
\text { Blastulation rates with respect } \\
\text { to high and low DFI are not } \\
\text { mentioned }\end{array}$ & SCSA & \\
\hline 3 & Virro et al. [50] & IVF and or ICSi & $\begin{array}{l}\text { Retrospective study } \\
n=249 \text { cycles } \\
\text { Low DFI }=178 \\
\text { High DFI }=71\end{array}$ & SCSA & \\
\hline 4 & Huang et al. [22] & IVF/ICSI & $\begin{array}{l}\text { Retrospective study } \\
n=303 \text { cycles }\end{array}$ & TUNEL & \\
\hline 5 & Breznik et al. [37] & IVF/ICSI & $\begin{array}{l}\text { Prospective study } \\
883 \text { cycles for IVF } \\
878 \text { cycles for ICSI }\end{array}$ & Sperm function tests & \\
\hline 6 & Anifandis et al. [2] & IVF/ICSI & $\begin{array}{l}\text { Prospective study } \\
n=156 \text { cycles } \\
\text { Low DFI } n=71 \\
\text { High DFI } n=85\end{array}$ & SCD & \\
\hline 7 & Simon et al. [45] & IVF/ICSI & $\begin{array}{l}\text { Prospective study } \\
n=238 \text { cycles only } \\
\text { sperm DNA damage } \\
\text { was studied using the } \\
3 \text { assays } \\
\text { COMET assay } n=238 \\
\text { TUNEL assay } n=235 \\
\text { FCCE } n=102\end{array}$ & $\begin{array}{l}\text { COMET } \\
\text { TUNEL } \\
\text { SCSA (FCCE) }\end{array}$ & \\
\hline 8 & Muriel et al. [30] & IVF/ICSI & $\begin{array}{l}\text { Prospective study } \\
n=85 \text { cycles }\end{array}$ & SCD & \\
\hline 9 & Loutradi et al. [28] & ICSI & $\begin{array}{l}\text { Prospective study } \\
n=219 \text { cycles } \\
\text { Since semen analysis was used, } \\
\text { we could not categorize as low } \\
\text { DFI or high DFI }\end{array}$ & Semen analysis & \multirow[t]{2}{*}{$\begin{array}{l}\text { Threshold for low and high DFI } \\
\text { was not defined inappropriate } \\
\text { inclusion of only high DFI } \\
\text { Only patients with high DFI were } \\
\text { considered and subjected to } \\
\text { intervention }\end{array}$} \\
\hline 10 & Greco et al. [19] & ICSI & $\begin{array}{l}\text { prospective study } \\
n=38 \text { cycles }\end{array}$ & TUNEL & \\
\hline 11 & Denomme et al. [11] & ICSI & $\begin{array}{l}\text { Prospective study } \\
n=246 \text { cycles }\end{array}$ & $\begin{array}{l}\text { Methylome and transcriptome } \\
\text { analysis }\end{array}$ & $\begin{array}{l}\text { DNA fragmentation index was } \\
\text { not studied. Sperm DNA meth- } \\
\text { ylation defects were studied } \\
\text { Since methylome and transcrip- } \\
\text { tome analysis was done, there } \\
\text { were no DFI categorization }\end{array}$ \\
\hline 12 & Piccolomini et al. [36] & IVF/ICSI & $\begin{array}{l}\text { Retrospective study } \\
n=4205 \text { cycles } \\
\text { Since semen analysis was used, } \\
\text { we could not categorize as low } \\
\text { DFI or high DFI }\end{array}$ & $\begin{array}{l}\text { Semen analysis as per WHO } \\
\text { recommendations }\end{array}$ & $\begin{array}{l}\text { DNA fragmentation index was } \\
\text { not studied. Processed sperms } \\
\text { were analyzed }\end{array}$ \\
\hline 13 & Yang et al. [53] & ICSI & $\begin{array}{l}\text { Prospective study } \\
n=90 \text { cycles } \\
\text { High DFI }=60 \\
\text { Low DFI }=30\end{array}$ & DFI assay was not mentioned & $\begin{array}{l}\text { Assay for sperm DNA fragmenta- } \\
\text { tion was not mentioned }\end{array}$ \\
\hline
\end{tabular}


a

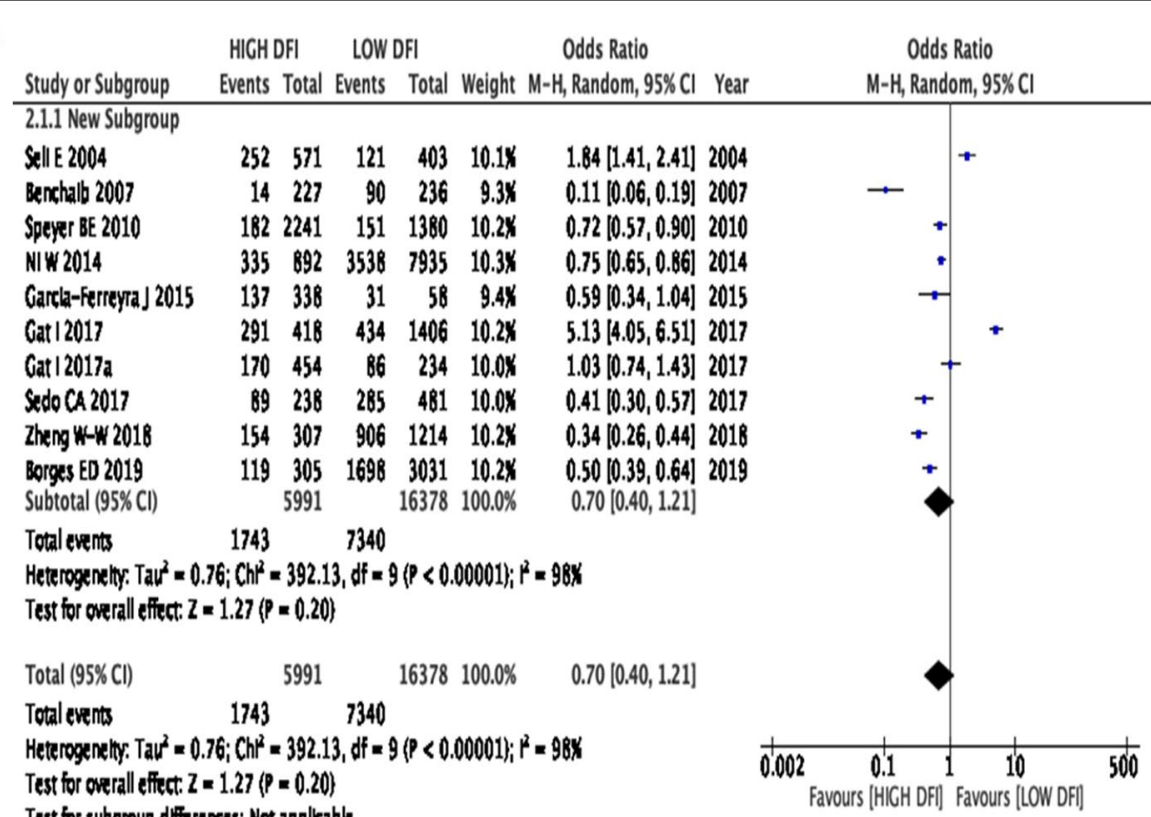

b

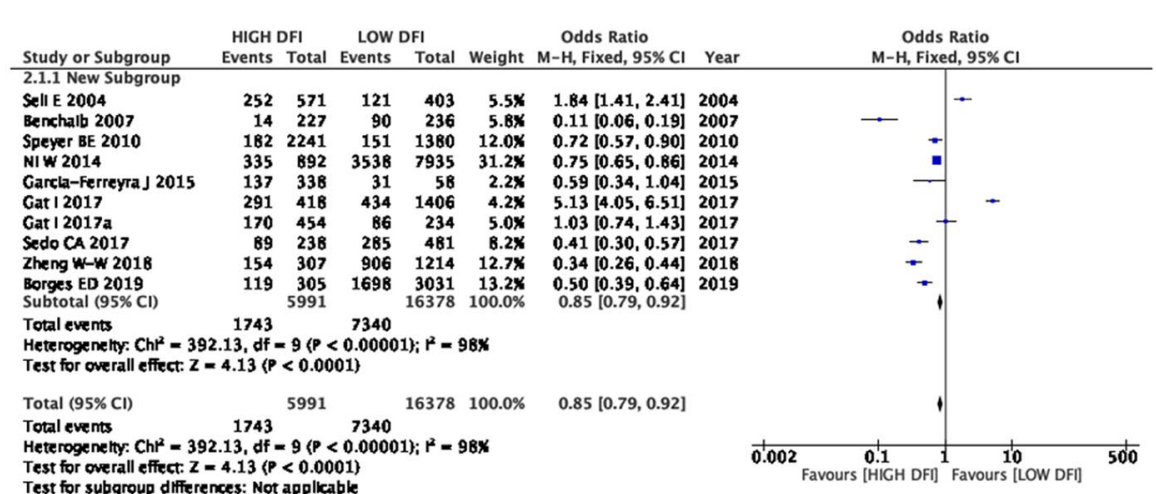

Fig. 2 Comparison of blastulation rate in high DFI and low DFI (random). b Comparison of blastulation rate in high DFI and low DFI (fixed)

The combined pooled odds ratio with confidence intervals are as follows pooled random $\mathrm{OR}=1.07 ; 95 \%$ $\mathrm{CI}=0.35$ to $3.25 ; \quad P=0.92 ; I^{2}$ (inconsistency) $=92 \%$ and pooled fixed $\mathrm{OR}=1.49 ; 95 \% \mathrm{CI}=1.17$ to 1.89 ; $P=0.001$.

The blastulation rates in the two studies were pooled, and a significant increase in blastulation rates was observed in the high DFI group.

The combined pooled odds ratio with confidence intervals are as follows: pooled random $\mathrm{OR}=0.44 ; 95 \%$ $\mathrm{CI}=0.23$ to $0.83 ; P=0.01 ; I^{2}$ (inconsistency) $=94 \%$ and pooled fixed $\mathrm{OR}=0.63 ; 95 \% \mathrm{CI}=0.55$ to $7.2 ; P<0.0001$.

\section{Heterogeneity (inconsistency) of the studies included} for the meta-analysis

The overall heterogeneity of the effects among the evaluated studies was high $\left(I^{2}=98 \%\right)$. Heterogeneity remained high even after the subgroup analysis based on types of DNA assay (SCD, TUNEL, and SCSA) and types of ART treatments (ICSI, IVF + ICSI, and IVF).

Among these studies, there were differences in study design, selection of subjects, and definition of low and high DFI cutoff threshold values for DNA damage (for a given assay).

\section{Discussion}

To the best of our knowledge, this is the first systematic review and meta-analysis to evaluate the effect of sperm DNA fragmentation on the rate of blastocyst formation (blastulation).

According to our meta-analysis, there is an overall non-significant increase in the blastocyst formation rate in the high sperm DNA fragmentation/damage (high 


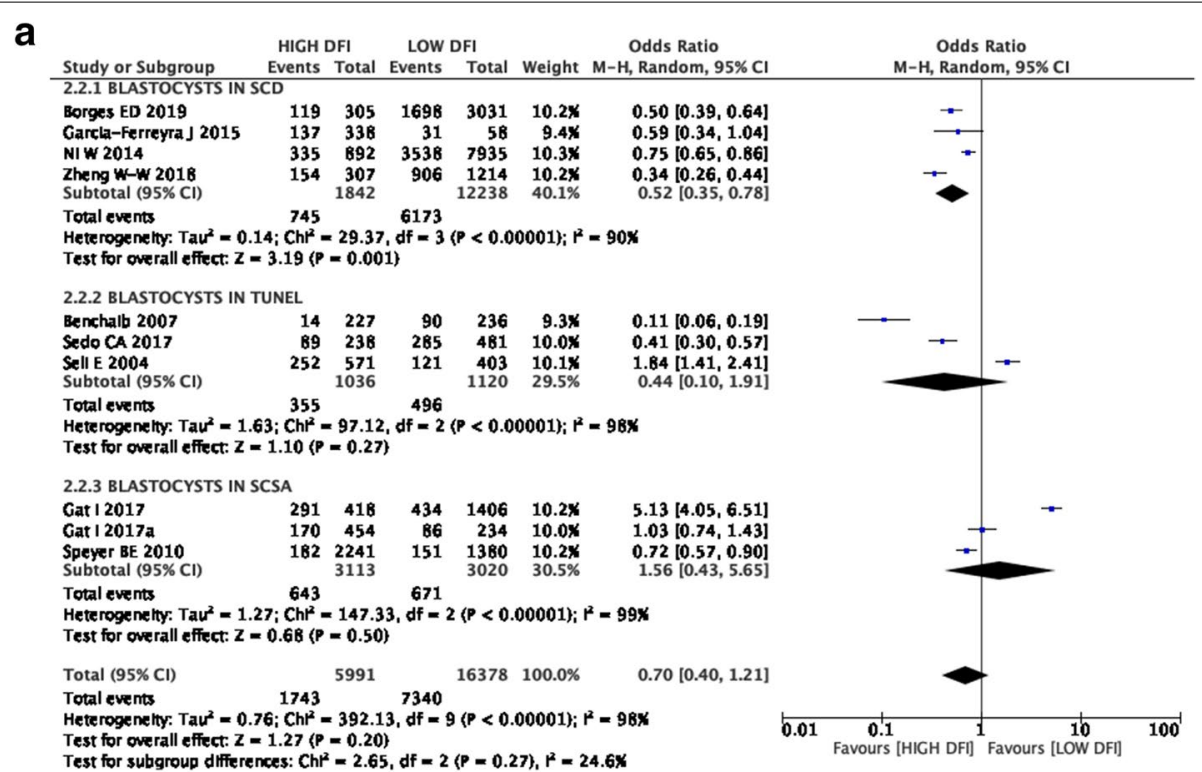

b

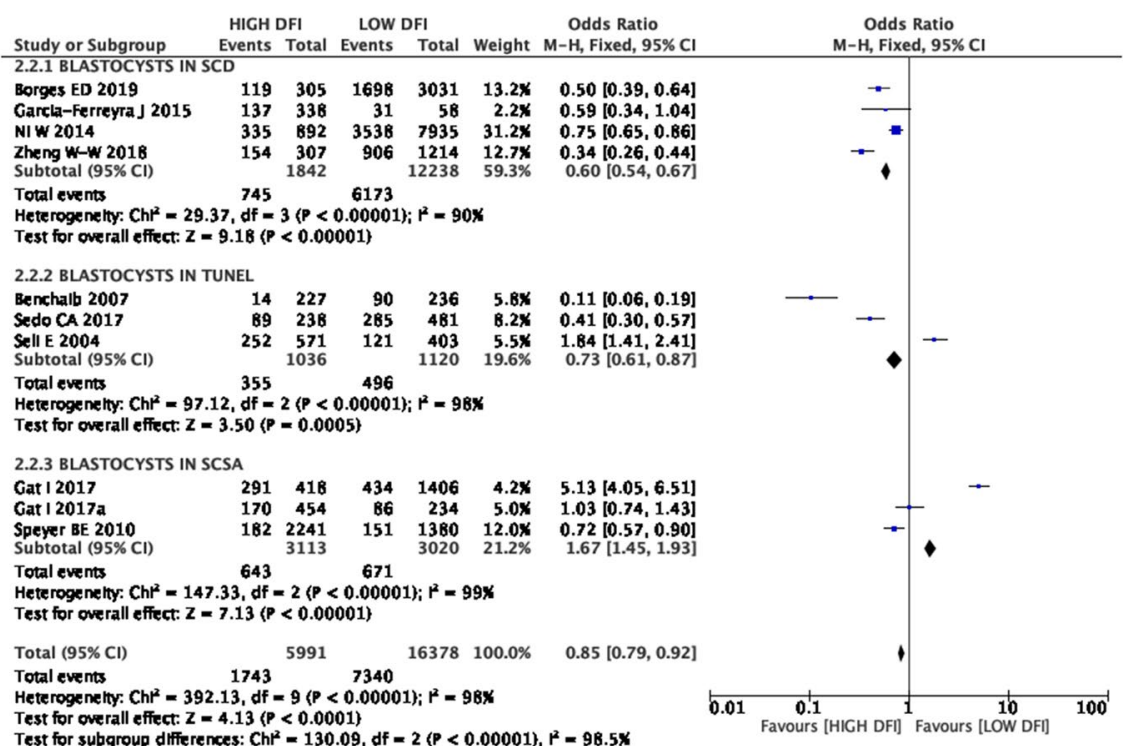

Fig. 3 a Comparison of blastulation rates in different sperm DNA assays (random). b Comparison of blastulation rates in different sperm DNA assays (fixed)

DFI) group in comparison to the low DFI group. The random pooled OR was 0.70 with a CI of $0.40-1.21$ and a $P$ value of 0.20 .

When we did subgroup analysis in different types of sperm DNA assays used to evaluate sperm DNA damage and in different types of ART procedures, we found that the similar positive trend (higher blastulation rates) in the high DFI group with SCD and TUNEL assays but blastulation rates were better in low DFI group with SCSA.
We noticed a slight positive effect on blastulation rates (higher blastulation rates) in the high DFI group when IVF was used as a method of ART, and there was no difference in blastulation rates between high and low DFI groups when ICSI or when mixed IVF + ICSI is used as methods of ART.

So far, all the published meta-analyses [10, 27, 35, 39, $46,55]$ studied the effect of high DNA sperm fragmentation on pregnancy rates and miscarriage rates but did not address the causal relationship between sperm DNA 


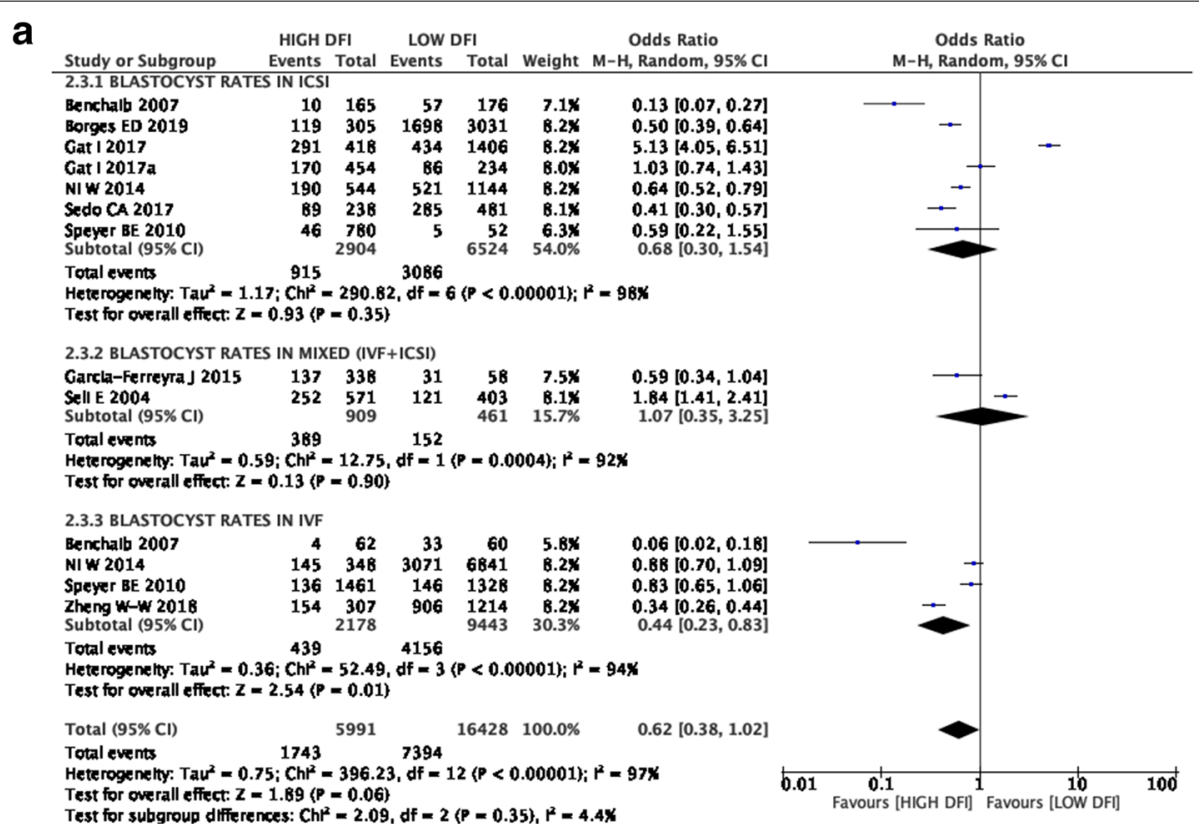

b

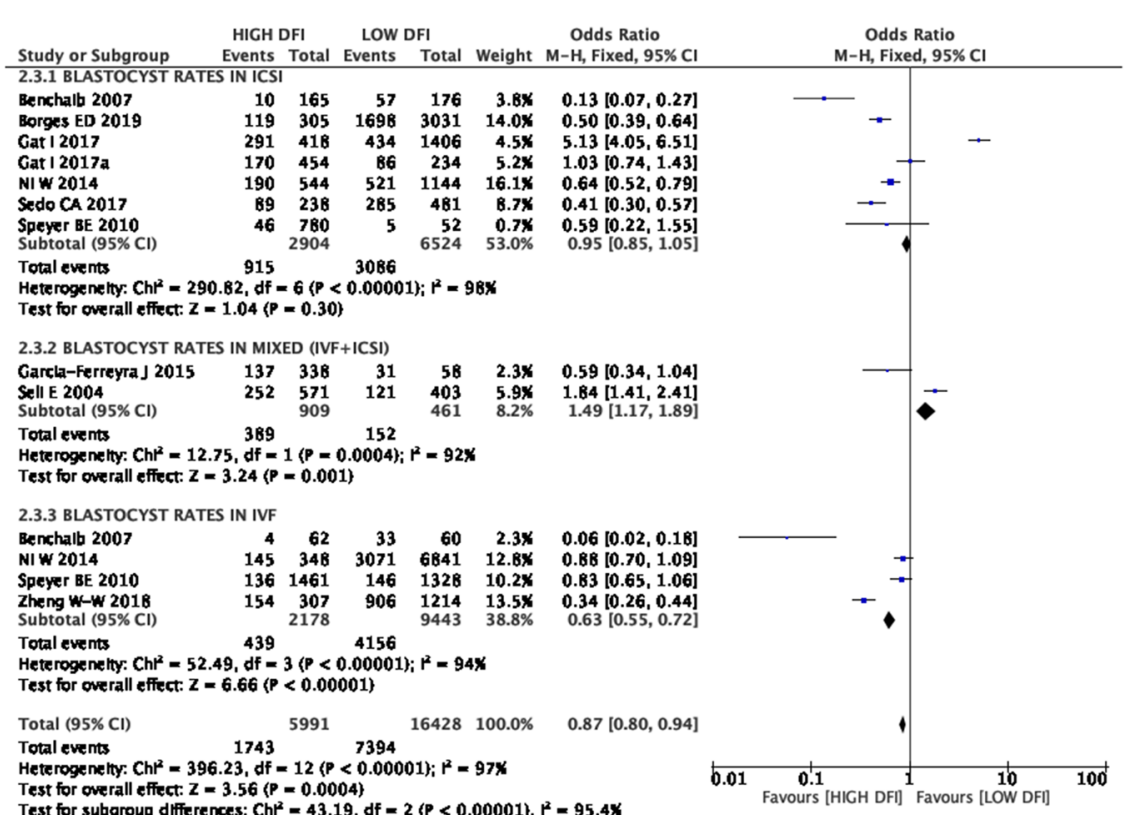

Fig. 4 a Comparison of blastulation rates in different ART methods (random). b Comparison of blastulation rates in different ART methods (fixed)

fragmentation and the blastulation rates, the crucial step for any pregnancy and its related outcomes. Pregnancy rates and miscarriage rates in ART are dependent and confounded by other female factors like elevated levels of progesterone on the day of hCG trigger, fresh and frozen embryo transfers not just limited to high sperm DNA fragmentation. Hence, pregnancy rates and miscarriage rates are not true reflections of blastulation rates in men with high DNA sperm fragmentation.

It is assumed that poor rate of blastocyst formation (blastulation rates) with high sperm DNA fragmentation is the plausible cause for the low pregnancy rates and this may be due to the embryonic arrest (inactivation of paternal embryonic genome, i.e., failure of $4-8$ cell stage embryo to form blastocyst) [6]. 
The overall slight improvement of blastulation rates with high sperm DNA fragmentation (high DFI) in our study is not entirely supportive of the above hypothesis. Seven out of ten studies had a combined odds ratio of just less than unity favoring a high DFI group with a small increase in blastulation rates. This increase may be due to the inherent ability of the oocyte to repair the effect of fertilizing sperm DNA damage. However, the oocyte loses its ability to repair with increasing maternal age, poor ovarian reserve, and poor quality of oocytes retrieved [18]. The inclusion of subjects with lower maternal age may be the reason for better blastulation rates in our analysis with high DFI. The largest study included in our analysis [34] which represents 31\% in our analysis had subjects with maternal age of less than 32 years concluded that no significant association between sperm DNA fragmentation and pregnancy outcomes. The younger age of the women might have compensated for the male factor. Studies by Gat et al., [17] are also in agreement with the same, where the donor oocytes were used for ICSI.

Another factor which might have influenced our results is the variable threshold cutoff levels for high DNA fragmentation in the studies included in our analysis. Seven out ten studies had threshold cutoff levels for high DNA fragmentation when DFI $>15 \%$ and three studies had when DFI $>30 \%$. It is possible that the average DFI in the high DFI group might be closer to the lower threshold cutoff values which might have resulted in better blastulation rates in the high DFI group especially if the high DFI threshold cutoff is $>15 \%$.

\section{Blastulation rates in different sperm DNA fragmentation assays}

The blastulation rates favor high sperm DNA fragmentation (high DFI) in SCD and TUNEL assays, which is similar to overall blastulation rates and favors low DFI in SCSA. The SCD assay was used for sperm DNA fragmentation in four studies and accounts for $60 \%$ weightage in the meta-analysis. TUNEL and SCSA were used in three studies each, respectively. No studies with COMET analysis were included in the meta-analysis. The SCSA assay demonstrates more negative effects of sperm with high DFI on blastulation rate than with other two assays (SCD and TUNEL). This may be related to the lower threshold cutoff value for sperm DNA fragmentation used in all three studies $(<15 \%)$, whereas in SCD and TUNEL assays lower threshold cutoff value for sperm DNA fragmentation varied from 15 to $30 \%$.

Blastulation rates with TUNEL and SCD assays from our review may be comparable to the pregnancy rates of the previous metanalysis done by Simon et al. [46] but not with meta-analysis done by Li et al. [27] in the high DFI group. In contrast, blastulation rates of our review with SCSA assay are not comparable to pregnancy rates reported by Simon et al. [46] and Li et al. [27] in their meta-analysis.

The SCD and SCSA assays are indirect tests and measure possible single-strand DNA damage after denaturation where as the TUNEL assay is the direct test and measures actual double-stranded DNA damage. TUNEL assay is more predictive of the outcomes with the sperm DNA damage, but the high interoperable variation and lack of standardization makes it unreliable. On the other hand, SCD and SCSA are easily reproducible and less interoperable variability makes it user-friendly.

Despite differences in the principle and methodology of these assays, the levels of DNA damage measured by these assays show some degree of correlation. This is in agreement with studies done by Nasr-Esfahani et al., [32, 33] and Henkel et al., [21].

\section{Blastulation rates in different methods of ART (IVF/ IVF+ ICSI/ICSI)}

Our meta-analysis did not demonstrate any significant difference in the blastulation rates between high DFI and low DFI groups when ICSI was employed as a method of ART but demonstrated an increase in the blastulation rates when IVF is employed as a method of ART, and favors low DFI group when mixed IVF + ICSI ART method is employed.

Our blastulation results with ICSI or IVF do not correlate with previous meta-analysis done by Osman et al. [35], Zhao et al. [55], and Li et al. [27], where the rates of fertilization improved when ICSI was employed as a method of ART in comparison to IVF. Instead, our blastulation rates were better with IVF in the high DFI group, and this may be due to the fact that in IVF process only the sperm with less DNA damage will be naturally selected which has better capacity and ability to fertilize and divide to form blastocysts.

Our results of no difference in blastulation rates in the high and low DFI group with ICSI agrees with pregnancy rates reported by Simon et al. [46] and Cissen et al. [10], but not with Zhao et al. [55]; Osman et al. [35]; Zini et al., [57]; Li et al. [27]; Evenson and Wixon, [13], based on the hypothesis that morphologically normal-looking sperm selected for the ICSI in high DFI group (high damaged sperm DNA) may bypass or will have reduced impact of robust rigors of the normal fertilization and will lead to better fertilization rates [26].

The results of this study emphasize the importance of sperm DNA fragmentation (sperm DNA damage) as a marker for blastocyst formation rather than pregnancy rates. 
Strategies like lifestyle modifications, antioxidant therapies, infection control, varicocele repair, ICSI, intracytoplasmic morphologically selected sperm (IMSI), and physiologic ICSI) are available to improve the sperm damage prior to ART procedure [23] and subsequently better blastocyst formation rates and pregnancies. However, the above findings need to be interpreted with caution because of high heterogeneity in the study population, mixture of prospective and retrospective studies without randomization, different threshold levels applied to define low- and highDNA sperm fragmentation among the studies, lack of standardization (due to intra- and intervariability among the different assays), and the inability of these assays to predict the actual DNA damage of the sperm which will fertilize the oocyte irrespective of the ART methods.

\section{Limitations}

First, the extreme heterogeneity in the study populations makes it difficult to draw concrete conclusions on the effects of sperm DNA damage (high DFI) on the blastocyst formation. Second, meta-analysis suggests sperm DNA damage may not affect blastocyst formation. However, studies summarizing the relationship between sperm DNA damage and blastocyst formation were of low quality (lack of RCTs on this subject). Nevertheless, the effect of high-sperm DNA fragmentation on blastulation rates warrants further adequately powered and well-designed randomized studies with standardized threshold cutoff levels of DFI for individual assays.

\section{Conclusion}

In conclusion, this study emphasizes on sperm DNA fragmentation (sperm DNA damage) as an important marker of blastocyst formation. The results of this meta-analysis suggest that the high-sperm DNA fragmentation may not significantly affects the fertilization or blastocyst formation.

Nevertheless, the effect of high-sperm DNA fragmentation on blastulation rates warrants further adequately powered and well-designed randomized studies with agreed threshold cutoff levels with the individual assay. This is not only to understand the implications of sperm DNA fragmentation tests on fertilization/blastocyst formation, pregnancy rates, and miscarriage rates but also to assess the role of therapeutic interventions such as lifestyle modifications, antioxidant therapies, infection control, varicocele repair, ICSI, intracytoplasmic morphologically selected sperm (IMSI), physiologic
ICSI to improve the sperm damage prior to ART procedure, and subsequently better blastocyst formation rates and pregnancies.

\begin{abstract}
Abbreviations
ART: Assisted reproductive technology; Cl: Confidence interval; DNA: Deoxyribonucleic acid; DFI: DNA fragmentation Index; ICSI: Intracytoplasmic sperm injection; IMSI: Intracytoplasmic morphologically selected sperm; IVF: In vitro fertilization; M II: Metaphase Il; MeSH: Medical Subjects Headings; OR: Odds ratio; PRISMA: Preferred Reporting Items for Systematic Reviewsand MetaAnalyses; RevMan: Reviewmanager; SCD: Sperm chromatindispersion; SCSA: Sperm chromatinstructure assay; TUNEL:Terminaldeoxynucleotidyl transferase dUTP nick end labelling.
\end{abstract}

\section{Acknowledgements}

Dr. Ravi Shankar, Assistant Professor, Department of Biostatistics, Vallabhbhai Patel Chest Institute, University of Delhi, India, for statistical input. Dr. Sanjay Karnati for an independent critical review of the draft.

\section{Authors' contributions}

SV and PK wrote the protocol and manuscript. SV, PK, and SR managed the literature search and SV and SR performed calculations, estimations, and metaanalysis in RevMan. All authors critically revised the manuscript and approved the final version.

\section{Funding}

No external funding was either sought or obtained for this study.

\section{Availabilityof data and materials}

N/A

\section{Declarations}

Ethics approval and consent to participate

Not applicable.

\section{Consent for publication}

Not applicable.

\section{Competing interests}

The authors declare that they have no competing interests.

\section{Author details}

${ }^{1}$ Department of Reproductive Medicine and Surgery, Kasturba Medical College Manipal, Manipal Academy of Higher Education, Manipal, India. ${ }^{2}$ Aberdeen Fertility Centre and Aberdeen Royal Infirmary, Aberdeen, UK. ${ }^{3}$ Honorary Associate University of Aberdeen, Aberdeen, UK. ${ }^{4}$ Ovum Fertility Centre \& Ovum Hospitals, Bengaluru, India.

Received: 3 February 2021 Accepted: 5 July 2021

Published online: 12 October 2021

\section{References}

1. Ajduk A, Zernicka-Goetz M (2013) Quality control of embryo development. Mol Aspects Med 34(5):903-918. https://doi.org/10.1016/j.mam. 2013.03.001

2. Anifandis G, Bounartzi T, Messini Cl, Dafopoulos K, Markandona R, Sotiriou S, Tzavella A, Messinis IE (2015) Sperm DNA fragmentation measured by Halosperm does not impact on embryo quality and ongoing pregnancy rates in IVF/ICSI treatments. Andrologia 47(3):295-302. https://doi.org/10. 1111/and.12259

3. Benchaib M, Braun V, Lornage J, Hadj S, Salle B, Lejeune H, Guérin JF (2003) Sperm DNA fragmentation decreases the pregnancy rate in an assisted reproductive technique. Hum Reprod (Oxford, England) 18(5):1023-1028. https://doi.org/10.1093/humrep/deg228 
4. Benchaib M, Lornage J, Mazoyer C, Lejeune H, Salle B, François Guerin $J$ (2007) Sperm deoxyribonucleic acid fragmentation as a prognostic indicator of assisted reproductive technology outcome. Fertil Steril 87(1):93-100. https://doi.org/10.1016/j.fertnstert.2006.05.057

5. Borges E Jr, Zanetti BF, Setti AS, Braga D, Provenza RR, laconelli A Jr (2019) Sperm DNA fragmentation is correlated with poor embryo development lower implantation rate, and higher miscarriage rate in reproductive cycles of non-male factor infertility. Fertil Steril 112(3):483-490. https:// doi.org/10.1016/j.fertnstert.2019.04.029

6. Braude P, Bolton V, Moore S (1988) Human gene expression first occurs between the four-and eight-cell stages of preimplantation development. Nature 332(6163):459-461. https://doi.org/10.1038/332459a0

7. Brugh VM 3rd, Lipshultz LI (2004) Male factor infertility: evaluation and management. Med Clin North Am 88(2):367-385. https://doi.org/10. 1016/S0025-7125(03)00150-0

8. Chen L, Fang J, Jiang W, et al (2020) Effects of the sperm DNA fragmentation index on the clinical and neonatal outcomes of intracytoplasmic sperm injection cycles. J Ovarian Res 13:52. https://doi.org/10.1186/ s13048-020-00658-z

9. Chi HJ, Kim SG, Kim YY, Park JY, Yoo CS, Park IH, Sun HG, Kim JW, Lee KH, Park HD (2017 Sep) ICSI significantly improved the pregnancy rate of patients with a high sperm DNA fragmentation index. Clin Exp Reprod Med. 44(3):132-140. https://doi.org/10.5653/cerm.2017.44.3.132. Epub 2017 Sep 26. PMID: 29026719; PMCID: PMC5636925

10. Cissen M, Wely MV, Scholten I, Mansell S, Bruin JP, Mol BW, Braat D, Repping $S$, Hamer G (2016) Measuring sperm DNA fragmentation and clinical outcomes of medically assisted reproduction: a systematic review and meta-analysis. PLoS ONE 11(11):e0165125. https://doi.org/10.1371/journ al.pone.0165125

11. Denomme MM, McCallie BR, Parks JC, Booher K, Schoolcraft WB, KatzJaffe MG (2018) Inheritance of epigenetic dysregulation from male factor infertility has a direct impact on reproductive potential. Fertil Steril 110(3):419-428.e1. https://doi.org/10.1016/j.fertnstert.2018.04.004

12. Dumoulin JC, Land JA, Van Montfoort AP et al (2010) Effect of in vitro culture of human embryos on birthweight of newborns. Hum Reprod 25(3):605-612. https://doi.org/10.1093/humrep/dep456

13. Evenson DP, Wixon R (2006) Clinical aspects of sperm DNA fragmentation detection and male infertility. Theriogenology 65(5):979-991. https://doi. org/10.1016/j.theriogenology.2005.09.011

14. Evenson DP, Larson KL, Jost LK (2002) Sperm chromatin structure assay: its clinical use for detecting sperm DNA fragmentation in male infertility and comparisons with other techniques. Int J Androl 23:25-43

15. Gao Y, Zhang X, Xiong S, Han W, Liu J, Huang G (2015) Motile sperm organelle morphology examination (MSOME) can predict outcomes of conventional in vitro fertilization: a prospective pilot diagnostic study. Hum Fertil 18:258-264

16. García-Ferreyra J, Luna D, Villegas L, Romero R, Zavala P, Hilario R, DueñasChacón J (2015) High aneuploidy rates observed in embryos derived from donated oocytes are related to male aging and high percentages of sperm DNA fragmentation. Clin Med Insights Reprod Health 9:21-27. https://doi.org/10.4137/CMRH.S32769

17. Gat I, Tang K, Quach K, Kuznyetsov V, Antes R, Filice M, Zohni K, Librach $C$ (2017) Sperm DNA fragmentation index does not correlate with blastocyst aneuploidy or morphological grading. PLoS ONE 12(6):e0179002. https://doi.org/10.1371/journal.pone.0179002

18. González-Marín C, Gosálvez J, Roy R (2012) Types, causes, detection and repair of DNA fragmentation in animal and human sperm cells. Int J Mol Sci 13(11):14026-14052. https://doi.org/10.3390/ijms131114026

19. Greco E, Romano S, lacobelli M, Ferrero S, Baroni E, Minasi MG, Ubaldi F, Rienzi L, Tesarik J (2005) ICSI in cases of sperm DNA damage: beneficial effect of oral antioxidant treatment. Hum Reprod (Oxford, England) 20(9):2590-2594. https://doi.org/10.1093/humrep/dei091

20. Hekmatdoost A, Lakpour N, Sadeghi MR (2009) Sperm chromatin integrity: etiologies and mechanisms of abnormality, assays, clinical importance, preventing and repairing damage. Avicenna J Med Biotechnol 1(3):147-160

21. Henkel R, Hoogendijk CF, Bouic PJ, Kruger TF (2010) TUNEL assay and SCSA determine different aspects of sperm DNA damage. Andrologia 42:305-313

22. Huang CC, Lin DP, Tsao HM, Cheng TC, Liu CH, Lee MS (2005) Sperm DNA fragmentation negatively correlates with velocity and fertilization rates but might not affect pregnancy rates. Fertil Steril 84(1):130-140. https:// doi.org/10.1016/j.fertnstert.2004.08.042

23. Kim GY (2018) What should be done for men with sperm DNA fragmentation? Clin Exp Reprod Med 45(3):101-109. https://doi.org/10.5653/ cerm.2018.45.3.101

24. Küçük N et al (2018) Sperm DNA and detection of DNA fragmentations in sperm. Turkish J Urol 44(1):1-5. https://doi.org/10.5152/tud.2018.49321

25. Larson-Cook KL, Brannian JD, Hansen KA, Kasperson KM, Aamold ET, Evenson DP (2003) Relationship between the outcomes of assisted reproductive techniques and sperm DNA fragmentation as measured by the sperm chromatin structure assay. Fertil steril 80(4):895-902. https:// doi.org/10.1016/s0015-0282(03)01116-6

26. Lewis SE, John Aitken R, Conner SJ, Iuliis GD, Evenson DP, Henkel R, Giwercman A, Gharagozloo P (2013) The impact of sperm DNA damage in assisted conception and beyond: recent advances in diagnosis and treatment. Reprod Biomed Online 27(4):325-337. https://doi.org/10. 1016/j.rbmo.2013.06.014

27. Li Z, Wang L, Cai J, Huang H (2006) Correlation of sperm DNA damage with IVF and ICSI outcomes: a systematic review and meta-analysis. J Assisted Reprod Genetics 23(9-10):367-376. https://doi.org/10.1007/ s10815-006-9066-9

28. Loutradi KE, Tarlatzis BC, Goulis DG, Zepiridis L, Pagou T, Chatziioannou E, Grimbizis GF, Papadimas I, Bontis I (2006) The effects of sperm quality on embryo development after intracytoplasmic sperm injection. J Assisted Reprod Genetics 23(2):69-74. https://doi.org/10.1007/s10815-006-9022-8

29. Marteil G, Richard-Parpaillon L, Kubiak JZ (2009) Role of oocyte quality in meiotic maturation and embryonic development. Reprod Biol 9(3):203-224. https://doi.org/10.1016/s1642-431x(12)60027-8

30. Muriel L, Garrido N, Fernández JL, Remohí J, Pellicer A, de los Santos, M. J., \& Meseguer, M. (2006) Value of the sperm deoxyribonucleic acid fragmentation level, as measured by the sperm chromatin dispersion test, in the outcome of in vitro fertilization and intracytoplasmic sperm injection. Fertil Steril 85(2):371-383. https://doi.org/10.1016/j.fertnstert.2005.07. 1327

31. Nagy ZP, Liu J, Joris H et al (1995) The result of intracytoplasmic sperm injection is not related to any of the three basic sperm parameters. Hum Reprod 10(5):1123-1129. https://doi.org/10.1093/oxfordjournals.humrep. a136104

32. Nasr-Esfahani MH, Razavi S, Travalaee M (2008) Failed fertilization after ICSI and spermiogenic defects. FertilSteril 89:892-898

33. Nasr-Esfahani MH, Razavi S, Vahdati AA, Fathi F, Tavalaee M (2008) Evaluation of sperm selection procedure based on hyaluronic acid binding ability on ICSI outcome. J AssistReprod Genet 25:197-203

34. Ni W, Xiao S, Qiu X, Jin J, Pan C, Li Y, Fei Q, Yang X, Zhang L, Huang X (2014) Effect of sperm DNA fragmentation on clinical outcome of frozen-thawed embryo transfer and on blastocyst formation. PLoS ONE 9(4):e94956. https://doi.org/10.1371/journal.pone.0094956

35. Osman A, Alsomait H, Seshadri S, El-Toukhy T, Khalaf Y (2015) The effect of sperm DNA fragmentation on live birth rate after IVF or ICSI: a systematic review and meta-analysis. Reprod Biomed Online 30(2):120-127. https:// doi.org/10.1016/j.rbmo.2014.10.018

36. Piccolomini MM, Bonetti TC, Motta E, Serafini PC, Alegretti JR (2018) How general semen quality influences the blastocyst formation rate: analysis of 4205 IVF cycles. JBRA Assisted Reprod 22(2):89-94. https://doi.org/10. 5935/1518-0557.20180022

37. Pregl Breznik B, Kovacic B, Vlaisavljevic V (2013) Are sperm DNA fragmentation, hyperactivation and hyaluronan-binding ability predictive for fertilization and embryo development in in vitro fertilization and intracytoplasmic sperm injection? Fertil Steril. 99:1233-41

38. Review Manager software (Review Manager [RevMan] (2014). Copenhagen: The Nordic Cochrane Centre, The Cochrane Collaboration.

39. Robinson L, Gallos ID, Conner SJ, Rajkhowa M, Miller D, Lewis S, KirkmanBrown J, Coomarasamy A (2012) The effect of sperm DNA fragmentation on miscarriage rates: a systematic review and meta-analysis. Hum Reprod (Oxford, England) 27(10):2908-2917. https://doi.org/10.1093/humrep/ des261

40. Samplaski MK, Agarwal A, Sharma R, Sabanegh E (2010) New generation of diagnostic tests for infertility: review of specialized semen tests. Int J Urol 17:839-847

41. Schlegel PN, Sigman M, Collura B, De Jonge CJ, Eisenberg ML, Lamb DJ, Mulhall JP, Niederberger C, Sandlow JI, Sokol RZ, Spandorfer SD, Tanrikut 
C, Treadwell JR, Oristaglio JT, Zini A (2021) Diagnosis and treatment of infertility in men: AUA/ASRM guideline part I. Fertil Steril 115(1):54-61. https://doi.org/10.1016/j.fertnstert.2020.11.015 (Epub 2020 Dec 9 PMID: 33309062

42. Scott L (2003) Pronuclear scoring as a predictor of embryo development. Reprod Biomed Online. 6(2):201-214. https://doi.org/10.1016/s14726483(10)61711-7

43. Sedó C, Bilinski M, Lorenzi D, Uriondo H, Noblía F, Longobucco V, Lagar EV, Nodar F (2017) Effect of sperm DNA fragmentation on embryo development: clinical and biological aspects. JBRA Assisted Reprod 21(4):343350. https://doi.org/10.5935/1518-0557.20170061

44. Seli E, Gardner DK, Schoolcraft WB, Moffatt O, Sakkas D (2004) Extent of nuclear DNA damage in ejaculated spermatozoa impacts on blastocyst development after in vitro fertilization. Fertil Steril 82(2):378-383. https:// doi.org/10.1016/j.fertnstert.2003.12.039

45. Simon L, Liu L, Murphy K, Ge S, Hotaling J, Aston Kl, Emery B, Carrell DT (2014) Comparative analysis of three sperm DNA damage assays and sperm nuclear protein content in couples undergoing assisted reproduction treatment. Hum Reprod (Oxford, England) 29(5):904-917. https://doi. org/10.1093/humrep/deu040

46. Simon L, Zini A, Dyachenko A, Ciampi A, Carrell DT (2017) A systematic review and meta-analysis to determine the effect of sperm DNA damage on in vitro fertilization and intracytoplasmic sperm injection outcome. Asian J Androl 19(1):80-90. https://doi.org/10.4103/1008-682X.182822

47. Smith R, Kaune H, Parodi D, Maradiaga M (2006) Rios R Morales I Castro A Increased sperm DNA damage in patients with varicocele: relationship with seminal oxidative stress. Hum Reprod 21:986-993

48. Speyer BE, Pizzey AR, Ranieri M, Joshi R, Delhanty JD, Serhal P (2010) Fall in implantation rates following ICSI with sperm with high DNA fragmentation. Hum Reprod (Oxford, England) 25(7):1609-1618. https://doi.org/10. 1093/humrep/deq116

49. Terriou P, Giorgetti C, Hans E, Salzmann J, Charles O, Cignetti L, Avon C, Roulier R (2007) Relationship between even early cleavage and day 2 embryo score and assessment of their predictive value for pregnancy. Reprod Biomed Online 14(3):294-299

50. Virro MR, Larson-Cook KL, Evenson DP (2004) Sperm chromatin structure assay (SCSA) parameters are related to fertilization, blastocyst development, and ongoing pregnancy in in vitro fertilization and intracytoplasmic sperm injection cycles. Fertil Steril 81(5):1289-1295. https://doi.org/ 10.1016/j.fertnstert.2003.09.063
51. World Health Organization (2010) WHO laboratory manual for the examination and processing of human semen. World Health Organization, Geneva

52. Yang H, Li G, Jin H, Guo Y, Sun Y (2019 Aug) The effect of sperm DNA fragmentation index on assisted reproductive technology outcomes and its relationship with semen parameters and lifestyle. Transl Androl Urol. 8(4):356-365. https://doi.org/10.21037/tau.2019.06.22. PMID: 31555559; PMCID: PMC6732090

53. Yang SJ, LiT, Liu W, Li SJ, Xie N, Zhang C, Gao X, Liu XD (2018). Pre-implantation genetic screening in intracytoplasmic sperm injection for infertile patients with high sperm DNA fragmentation index. Zhonghua nan ke xue $=$ Nat J Androl. 24(1):39-44

54. Zhang Z, Zhu L, Jiang H, Chen H, Chen Y, Dai Y (2015 Jan) Sperm DNA fragmentation index and pregnancy outcome after IVF or ICSI: a meta-analysis. J Assist Reprod Genet. 32(1):17-26. https://doi.org/10. 1007/s10815-014-0374-1. Epub 2014 Nov 13. PMID: 25392073; PMCID: PMC4294868

55. Zhao J, Zhang Q, Wang Y, Li Y (2014) Whether sperm deoxyribonucleic acid fragmentation has an effect on pregnancy and miscarriage after in vitro fertilization/intracytoplasmic sperm injection: a systematic review and meta-analysis. Fertil Steril 102(4):998-1005.e8. https://doi.org/10. 1016/j.fertnstert.2014.06.033

56. Zheng WW, Song G, Wang QL, Liu SW, Zhu XL, Deng SM, Zhong A, Tan YM, Tan Y (2018) Sperm DNA damage has a negative effect on early embryonic development following in vitro fertilization. Asian J Androl 20(1):75-79. https://doi.org/10.4103/aja.aja_19_17

57. Zini A, Dohle G (2011) Are varicoceles associated with increased deoxyribonucleic acid fragmentation? Fertil Steril 96(6):1283-1287. https://doi. org/10.1016/j.fertnstert.2011.10.016

58. Zini A, Bielecki R, Phang D, Zenzes MT (2001) Correlations between two markers of sperm DNA integrity, DNA denaturation and DNA fragmentation, in fertile and infertile men. Fertil Steril 75:674-677

\section{Publisher's Note}

Springer Nature remains neutral with regard to jurisdictional claims in published maps and institutional affiliations.

\section{Submit your manuscript to a SpringerOpen ${ }^{\odot}$ journal and benefit from:}

- Convenient online submission

- Rigorous peer review

- Open access: articles freely available online

- High visibility within the field

- Retaining the copyright to your article

Submit your next manuscript at $\boldsymbol{\nabla}$ springeropen.com 